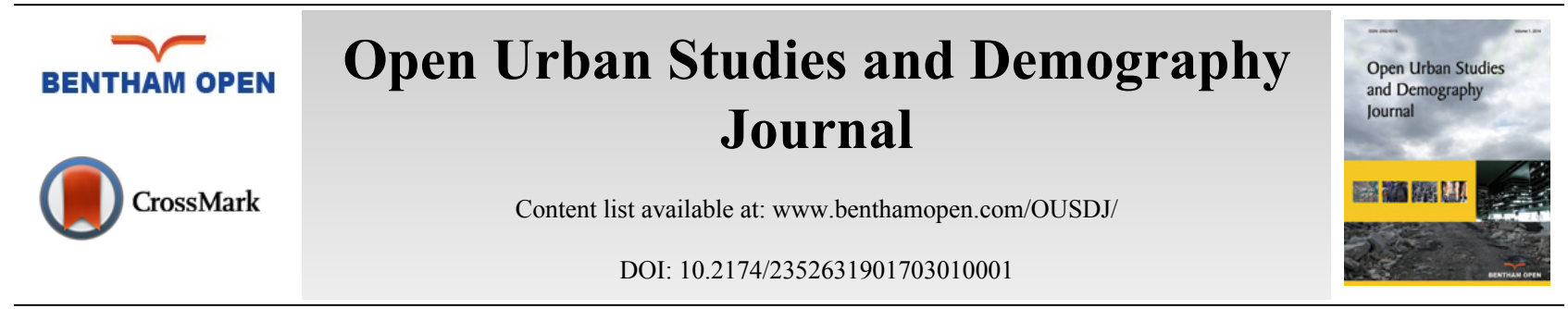

RESEARCH ARTICLE

\title{
Who Engages in Undeclared Work in Urban Europe? A Critical Evaluation of the Marginality Thesis
}

\author{
Colin C. Williams ${ }^{1, *}$ and Ioana A. Horodnic ${ }^{2}$ \\ ${ }^{I}$ Public Policy Management School, University of Sheffield, Sheffield, United Kingdom \\ ${ }^{2}$ Faculty of Economics and Business Administration Alexandru Ioan Cuza University of Iasi Romania, Iasi, Romania
}

Received: October 11, 2016

Revised: January 09, 2017

Accepted: January 09, 2017

\begin{abstract}
The view that undeclared work is undertaken by marginalised populations (i.e., those groups relatively excluded from the formal labour market) is a core assumption of not only modernisation theory, which holds that undeclared work is conducted by and for marginal population at the 'bottom of the pyramid', but also political economy theory, which views contemporary capitalism to outsource and subcontract production to the undeclared economy where marginalised populations conduct such work as a survival strategy. Until now however, few extensive evaluations of the validity of this marginality thesis have been conducted in relation to urban environments. To fill this gap, this paper reports data from a 2013 cross-national survey of urban populations in 28 European member states. Using multilevel mixed-effects logistic regression analysis, this reveals that although some marginalised groups in urban Europe (those having difficulties paying their household bills and younger age groups) are significantly more likely to participate in undeclared work, others are not (the unemployed) and yet others (women and urban dwellers in less affluent European regions) are significantly less likely to participate. The outcome is a more variegated theorisation of which marginal groups participate in undeclared work in urban areas and the need for policy towards the undeclared economy to address this more nuanced understanding.
\end{abstract}

Keywords: Europe, Informal sector, Marginalisation, Public policy, Undeclared work, Urban areas.

\section{INTRODUCTION}

A dominant view for several decades has been that marginalised populations (i.e., those that are relatively excluded from the formal labour market) are more likely to participate in undeclared work [1 - 3]. This marginality thesis holds that not only people are inhabiting marginalised areas, such as less affluent countries or peripheral rural areas, more likely to work in the undeclared economy [4, 5], but also are marginal socio-economic groups, such as women, the unemployed and those in financial difficulty [6 - 8]. Despite the dominance of this marginality thesis, the evidence-base supporting this view has been weaken, largely composed of small-scale studies of specific populations and localities [9 - 11]. In this paper, therefore, the aim is to evaluate this marginality thesis in relation to urban populations by reporting an extensive data set, namely a survey conducted in 28 European countries which included 17,886 face-to-face interviews with urban inhabitants.

To commence, the next section provides a brief review of the competing views on the participation of marginal populations in undeclared work. This will display that the dominant 'marginality thesis', which holds that marginal populations are more likely to work in the undeclared economy, is a central assumption of both modernisation and political economy explanations. However, with the advent of agency-oriented neo-liberal and institutional explanations which view undeclared work as a matter of choice rather than due to a lack of choice, questions have started to be raised about the validity of this marginality thesis. Revealing that the evidence supporting the marginality thesis is scarce and largely composed of small-scale surveys in specific localities or populations, the second section then begins to fill this

\footnotetext{
* Address correspondence to this author at the Management School, University of Sheffield, Sheffield S10 1FL, United Kingdom; Tel: +44 114 2223476; E-mail: c.c.williams@sheffield.ac.uk
} 
gap by introducing the methodology used in an extensive 2013 survey of participation in undeclared work across 28 European countries which included 17,886 face-to-face interviews with urban inhabitants. The third section reports which urban populations engaged in undeclared work in the European Union. This will reveal that whether marginal populations are more likely to work in the undeclared economy depends on which marginal groups are considered. Although some marginal populations are more likely to work in the undeclared economy, some are not, and yet others significantly less likely to do so. In the fourth and final section, conclusions are then drawn by discussing the implications for theory and policy of the findings.

At the outset, a definition of undeclared work is required. The widespread consensus in the literature is that undeclared work comprises paid activities not declared to the authorities for tax, social security and/or labour law purposes when they should be declared [12 - 16]. If a paid activity varies in additional ways to the formal economy, then this paid activity is not here defined as undeclared work. For instance, if illegal goods and/or services are traded, such as illegal drugs, then this paid activity is part of the broader 'criminal' economy rather than the undeclared economy, whilst if the activity is unpaid, it belongs to the wholly separate unpaid economy. However, blurred boundaries remain, including when activity is reimbursed using in-kind favours or gifts. Here, and mirroring the 2013 survey analysed, activity that is reimbursed in-kind or with gifts are excluded from the analysis. Also, we excluded from the analysis the declared employees in declared jobs who receive some of their wage as a declared salary and some as an additional undeclared ("envelope") wage. Instead, only activities that are wholly undeclared for tax, social security and/or labour law purposes are included.

\section{COMPETING PERSPECTIVES ON WHO ENGAGES IN UNDECLARED WORK}

The 'marginality thesis' holds that marginal populations, which are usually loosely defined, are more likely to participate in undeclared work [1 - 3]. This is the case both for inhabitants of marginalised places as well as marginal groups who are relatively excluded from the formal labour market. On the one hand, there has been a long-standing belief at all spatial scales that the undeclared economy is more prevalent in poorer areas. This is viewed as the case whether one is discussing global regions [4, 17], variations between nations [14, 18], local and regional variations [9, 16] or urban-rural variations [19, 20]. On the other hand, groups that are relatively marginalised from the formal labour market are also believed to be more likely to work in the undeclared economy. For example, the unemployed are believed to be more likely to work in the undeclared economy than those who have formal employment [6 - 8, 10, 21], women more likely than men $[5,10,11,22]$, and those with financial difficulties more likely to work in the undeclared economy than those without such difficulties [3, 23, 24].

This marginality thesis is a result of, and a key facet of, two dominant theoretical explanations of the undeclared economy. In modernisation theory, the undeclared economy is leftover from a previous regime that continues in peripheral enclaves that have not yet been subjected to modernisation and economic development. The undeclared economy is consequently seen to be disconnected from the formal economy and to be typically participated in by marginal groups such as the uneducated who operate small unproductive enterprises serving the 'bottom of the pyramid' market in that they produce poor quality products for less affluent consumers using little capital and adding little value $[25,26]$.

In political economy theory, meanwhile, the undeclared economy is seen as an inherent feature of an emergent deregulated global economy in which outsourcing and subcontracting are principal means by which undeclared work is integrated into contemporary capitalism so that production costs can be reduced [7, 8, 27, 28]. Accompanying deregulation is a reduction of state intervention in social protection causes those excluded from the formal labour market and social protection to be pushed into the undeclared economy as a last resort and survival practice $[5,8,28]$. In the political economy perspective, therefore, the undeclared economy is a 'necessity-driven' realm in which marginal populations excluded from the formal economy and social protection [21, 29].

However, this dominant marginality thesis has been regularly contested over the past few decades. Based on the view that necessity is not the sole universal determinant of participation in undeclared work, it has been argued that it is not always marginal populations who work in the undeclared economy. Indeed, several studies display that the undeclared economy is less rife in deprived regions and localities [16, 24, 30, 31], and that the unemployed participate less in undeclared work than those with formal jobs [32 - 35]. At least four reasons have been given for this finding. First, they lack the resources (such as a car or tools) required to participate in a wide range of undeclared work [24, 33], secondly, they receive and hear about fewer opportunities to work undeclared due to their smaller and more confined social networks [36 - 38], thirdly, they lack the skills and competencies to conduct undeclared work [34, 39] since if 
these are inadequate to find a formal job, they are also likely to be inadequate to find undeclared work; and fourth and finally, they fear detection from the authorities because claiming welfare benefits illicitly is commonly seen as a more serious misdemeanour than tax evasion [40, 41]. Women, moreover, are often found to participate less than men in the undeclared economy $[42,43]$, and those with financial difficulties are asserted to work less in the undeclared economy than those without such difficulties [44].

This questioning of the marginality thesis derives from agency-oriented theoretical explanations of the undeclared economy. On the one hand, neo-liberals have portrayed those working in the undeclared economy as rational economic actors who decide whether to operate undeclared by weighing up the costs of undeclared work and benefits of operating legitimately. For these scholars, high taxes, burdensome regulations and public sector corruption result in citizens voluntarily leaving the formal economy and turning to the undeclared economy [45 - 47]. On the other hand, another agency-oriented perspective has drawn upon institutional theory [48] and adopted a more 'social actor' approach which views work in the undeclared economy as illegal in the eyes of formal institutions but socially legitimate in the eyes of informal institutions (citizens' norms, values and beliefs) [49 - 55]. When symmetry exists between formal and informal institutions, undeclared work will only occur unintentionally such as when there is a lack of understanding of the laws and regulations. When institutional asymmetry exists nevertheless, work in the undeclared economy prevails. As such, the greater the asymmetry between formal and informal institutions, the more prevalent is work in the undeclared economy [56 - 60].

Till now, most studies (including those reported above) of who participates in undeclared work have been smallscale surveys of specific localities and/or population groups. Few, if any, extensive cross-national surveys have been conducted that examine who participates in undeclared work and thus test the validity of the marginality thesis in relation to urban populations. Here, therefore, we turn attention to a data-set which begins to fill this major gap.

\section{METHODOLOGY}

To evaluate the validity of the dominant marginality thesis, we here use the Special Eurobarometer No. 402. Using the same sampling method as other Eurobarometer surveys, 27,563 face-to-face interviews were undertaken during April and May 2013 in all 28 member states of the European Union, with some 500 conducted in smaller countries and 1,500 in larger nations. In every country, a multi-stage random (probability) sampling methodology was used which ensure that on the issues of gender, age, region and whether it is an urban or rural area, the sample was proportionate to the distribution of the population in each country. Some 17,886 face-to-face interviews were thus conducted with people living in urban areas. This population is here the focus of our analysis. In the descriptive analysis below, we use the sampling weighting scheme as suggested by the literature [61 - 63]. In the multivariate analysis nonetheless, there is debate over whether to do so or not [61 - 64]. Given that the majority opinion is that the weighting scheme should not be used, we here decided not to do so for the multivariate analysis.

The face-to-face interviews were in the national language with adults aged 15 years and older. The interviews built rapport with the participants before posing the more sensitive questions, starting off with questions about their attitudes towards the undeclared economy, followed by questions on which goods and services had been purchased on an undeclared basis by them. Only after this were questions put regarding their own participation in undeclared work. Examining the responses of the interviewers about their perceived reliability of the interviews conducted, cooperation of the respondents was deemed bad in just 1.1 per cent of the interviews completed. Cooperation was said to be excellent in 63.9 per cent, fair in 28,9 per cent and average in 6.1 per cent.

Given this, attention can turn to an analysis of the results. To do this, we here use multilevel mixed-effects logistic regression analysis. The dependent variable measures whether respondents participated in undeclared work and is based on the question 'Apart from regular employment, have you yourself carried out any undeclared paid activities in the last 12 months?'. The independent variables used to analyse whether marginalised populations are more likely to participate in undeclared work are divided into socio-demographic, socio-economic and spatial variables and are as follows:

- Socio-demographic independent variables: Gender $(1=$ males, $0=$ females $)$, Age $(1=15$ to 24 years old, $2=25$ to 39 years old, $3=40$ to 54 years old, $4=55$ years old and over $)$, Marital Status $(1=\mathrm{married} / \mathrm{remarried}, 2=$ cohabiters, 3 = singles, $4=$ separated or divorced, widowed and other form of marital status), People $15+$ years in own household $(1=$ one person, $2=$ two persons, $3=$ three persons, $4=$ four persons or more $)$, Children up to 14 years old in the household $(1=$ having children, $0=$ not having children), Tax morality index (Constructed index of self-reported tolerance towards tax non-compliance). 
- Socio-economic independent variables: Employment status $(1=$ employed respondents, $0=$ unemployed respondents), Difficulties paying bills ( $1=$ most of the time, $2=$ occasionally, $3=$ almost never/never $)$.

- Spatial independent variables: Area respondent lives $(1=$ large urban area, $0=$ small or middle sized town), Region $(1=$ Western Europe, 2 = Southern Europe, 3 = East-Central Europe, $4=$ Nordic nations $)$.

We kept in the analysis only the individuals for which data on each and every independent variable is available. Below, we report the findings.

\section{FINDINGS}

\section{Descriptive Statistics}

As Table 1 displays, 4 per cent of the respondents who live in urban areas reported that they had undertaken work in the undeclared economy over the past year, which is 1 in 25 of the citizens surveyed who will in urban areas in the 28 member states of the European Union (EU-28). The mean earnings of these urban dwellers who participate in undeclared work is $€ 662$.

Table 1. Participation in undeclared work in urban areas in EU-28: by socio-demographic characteristics, socio-economic status and region $(n=16,226)$.

\begin{tabular}{|c|c|c|c|c|}
\hline & \multirow{2}{*}{$\begin{array}{c}\text { Urban people engaged in undeclared } \\
\text { work }\end{array}$} & \multicolumn{3}{|c|}{ Earnings from undeclared work } \\
\hline & & Disclosed & Don't know; Refusal & Mean \\
\hline & $(\%)$ & $(\%)$ & $(\%)$ & $(€)$ \\
\hline All EU-28 & 4 & 73 & 27 & 662 \\
\hline \multicolumn{5}{|l|}{ Gender } \\
\hline Women & 3 & 75 & 25 & 618 \\
\hline Men & 5 & 71 & 29 & 693 \\
\hline \multicolumn{5}{|l|}{ Age } \\
\hline $15-24$ & 8 & 83 & 17 & 463 \\
\hline $25-39$ & 5 & 69 & 31 & 844 \\
\hline $40-54$ & 4 & 72 & 28 & 680 \\
\hline $55+$ & 1 & 54 & 46 & 770 \\
\hline \multicolumn{5}{|l|}{ Marital status } \\
\hline Married/Remarried & 2 & 68 & 32 & 730 \\
\hline Cohabitating & 7 & 67 & 33 & 537 \\
\hline Single & 7 & 84 & 16 & 664 \\
\hline Divorced/Separated/ Widowed/Other & 3 & 61 & 39 & 711 \\
\hline \multicolumn{5}{|c|}{ Number of persons $15+$ years in household } \\
\hline One & 5 & 73 & 27 & 668 \\
\hline Two & 3 & 74 & 26 & 733 \\
\hline Three & 4 & 73 & 27 & 648 \\
\hline Four and more & 5 & 69 & 31 & 473 \\
\hline \multicolumn{5}{|l|}{ Children } \\
\hline Not having children & 4 & 72 & 28 & 598 \\
\hline Having children & 4 & 76 & 24 & 785 \\
\hline \multicolumn{5}{|l|}{ Tax morality (mean=2.24) } \\
\hline Bellow mean & 2 & 69 & 31 & 628 \\
\hline Above mean & 7 & 74 & 26 & 673 \\
\hline \multicolumn{5}{|l|}{ Employment } \\
\hline Unemployed & 4 & 71 & 29 & 583 \\
\hline Employed & 4 & 74 & 26 & 736 \\
\hline \multicolumn{5}{|l|}{ Difficulty paying bills } \\
\hline Most of the time & 9 & 74 & 26 & 617 \\
\hline From time to time & 4 & 61 & 39 & 860 \\
\hline Almost never/never & 3 & 81 & 19 & 587 \\
\hline \multicolumn{5}{|l|}{ Urban area } \\
\hline Small/ middle sized town & 4 & 71 & 29 & 682 \\
\hline
\end{tabular}


(Table $\square$ ) contd......

\begin{tabular}{|c|c|c|c|c|}
\hline & \multirow{2}{*}{$\begin{array}{c}\text { Urban people engaged in undeclared } \\
\text { work }\end{array}$} & \multicolumn{3}{|c|}{ Earnings from undeclared work } \\
\hline & & Disclosed & Don't know; Refusal & Mean \\
\hline & $(\%)$ & $(\%)$ & $(\%)$ & (€) \\
\hline Large town & 4 & 76 & 24 & 634 \\
\hline \multicolumn{5}{|l|}{ Region } \\
\hline Western Europe & 4 & 83 & 17 & 548 \\
\hline Southern Europe & 2 & 59 & 41 & 1186 \\
\hline East-Central Europe & 4 & 53 & 47 & 479 \\
\hline Nordic Nations & 6 & 93 & 7 & 939 \\
\hline
\end{tabular}

To evaluate the marginality thesis, Fig. (1) displays how participation rates vary across the European Union, so as to understand whether urban inhabitants in the poor East-Central European and Southern European countries have higher participation rates than the urban inhabitants in the more affluent Nordic and Western European nations. The finding is that the countries in which urban inhabitants are most likely to engage in undeclared work are Estonia (where 13 per cent of urban dwellers had engaged in undeclared work in the prior 12 months), Latvia (11 per cent) and the Netherlands (10 per cent). At the opposite end, the countries with the lowest participation rate in undeclared work are Malta (with less than 1 per cent), Ireland (1 per cent) and Cyprus, Italy and Portugal ( 2 per cent). As such, the marginality thesis does not appear to hold at the European regional level in the sense that urban dwellers in the less affluent European regions do not appear to have higher participation rates in undeclared work than urban dwellers in the affluent European regions.

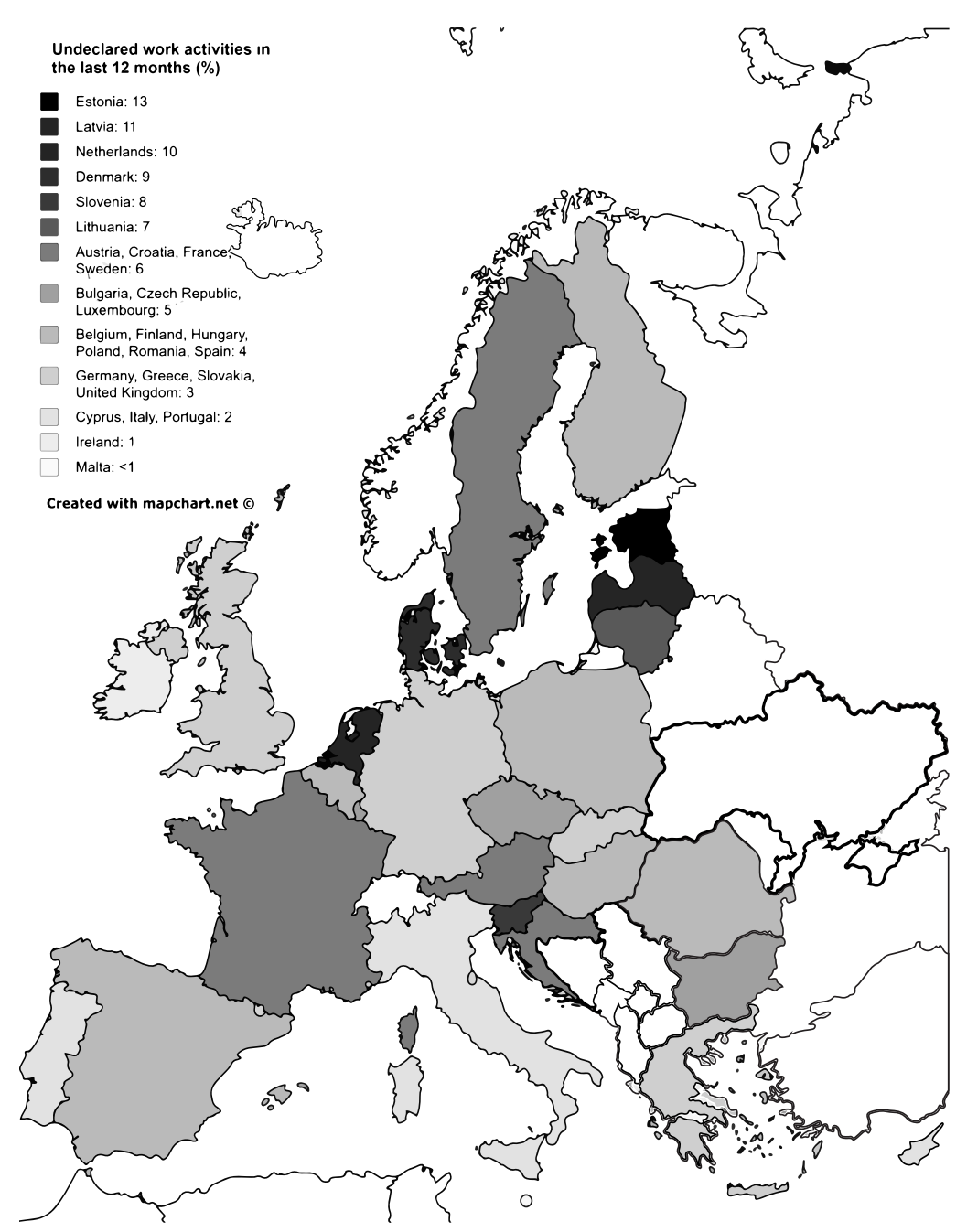

Fig. (1). Participation in undeclared work in urban areas in the past 12 months, by EU-28 country $(n=16,226)$. 
Turning to whether the marginality thesis applies on a socio-demographic, socio-economic and spatial level, Table $\mathbf{1}$ displays some mixed results. Contrary to the marginality thesis, participation in undeclared work is higher amongst urban men than urban women ( 5 per cent of urban men participated over the past 12 months compared with 3 per cent of urban women) and women earn less than men in urban areas from such work (i.e., 89 per cent the amount earned by men). Furthermore, the unemployed in urban areas are no more likely to participate in undeclared work than the employed and even when they do, their earnings are 76 per cent the amount earned by the employed. Neither do respondents living in small or middle sized towns participate in undeclared work to a greater extent than respondents living in large urban areas. The tentative suggestion from these descriptive statistics therefore, is that the marginality thesis does not apply when discussing gender, employment status and urban settlement size.

However, the marginality thesis does appear to be applicable when discussing younger age groups, who are more likely to participate in undeclared work than older age groups, and also to those who are not married compared with married/remarried participants, as well as those having difficulties paying bills compared with those seldom having such difficulties. For all these population groups, the marginality thesis appears to be valid. Analysing the descriptive statistics therefore, the tentative conclusion is that it is not possible to assert that the marginality thesis is universally applicable at all spatial scales and across all socio-demographic and socio-economic groups.

\section{Analysis}

We here analyse the hypothesis that participation in undeclared work significantly varies according to individual socio-demographic, socio-economic and spatial characteristics when other variables are taken into account and held constant. Given the hierarchical structure of the data (i.e., individuals nested within countries), for the multivariate analysis, we employ a multilevel model. As the dependent variable is dichotomous, we use a multilevel mixed-effects logistic regression [65]. Indeed, the likelihood-ratio test for the null hypothesis that there are no variations in participation in undeclared work reports that this hypothesis can be safely rejected. Therefore, the multilevel mixedeffects logistic regression should be the one used.

To analyse the association between the various independent variables and participation in undeclared work when other variables are held constant, an additive model is used. The first stage model (M1) includes solely the sociodemographic factors to examine their association, while the second stage model (M2) adds socio-economic factors alongside the socio-demographic factors, and the third stage model (M3) adds spatial factors to the socio-demographic and socio-economic factors to examine their association with the participation in undeclared work in urban Europe. Table 2 reports the results.

Table 2. Multilevel mixed-effects logistic regression of participation in undeclared work in urban areas.

\begin{tabular}{|c|c|c|c|}
\hline & Model 1 & Model 2 & Model 3 \\
\hline \multicolumn{4}{|l|}{ Gender (Women) } \\
\hline Men & $0.588 * * *(0.082)$ & $0.643 * * *(0.083)$ & $0.643 * * *(0.083)$ \\
\hline \multicolumn{4}{|l|}{ Age (15-24) } \\
\hline $25-39$ & $-0.226 *(0.123)$ & $-0.237 *(0.129)$ & $-0.231 *(0.129)$ \\
\hline $40-54$ & $-0.614 * * *(0.135)$ & $-0.646 * * *(0.141)$ & $-0.648 * * *(0.141)$ \\
\hline $55+$ & $-1.503 * * *(0.161)$ & $-1.512 * * *(0.162)$ & $-1.520 * * *(0.162)$ \\
\hline \multicolumn{4}{|l|}{ Marital status (Married/Remarried) } \\
\hline Cohabitating & $0.186(0.127)$ & $0.152(0.128)$ & $0.147(0.128)$ \\
\hline Single & $-0.007(0.141)$ & $-0.053(0.141)$ & $-0.046(0.141)$ \\
\hline Divorced/Separated/ Widowed/Other & $0.101(0.142)$ & $0.031(0.143)$ & $0.029(0.143)$ \\
\hline \multicolumn{4}{|c|}{ Number of persons $15+$ years in household (One) } \\
\hline Two & $-0.392 * * *(0.126)$ & $-0.371 * * *(0.126)$ & $-0.366^{* * *}(0.126)$ \\
\hline Three & $-0.351 * *(0.141)$ & $-0.328 * *(0.142)$ & $-0.322 * *(0.142)$ \\
\hline Four and more & $-0.366 * *(0.156)$ & $-0.331 * *(0.157)$ & $-0.318 * *(0.157)$ \\
\hline \multicolumn{4}{|l|}{ Children (Not having children) } \\
\hline Having children & $-0.036(0.101)$ & $-0.095(0.101)$ & $-0.105(0.102)$ \\
\hline Tax morality & $0.368 * * *(0.021)$ & $0.358 * * *(0.021)$ & $0.357 * * *(0.021)$ \\
\hline \multicolumn{4}{|l|}{ Employment (Unemployed) } \\
\hline Employed & & $-0.061(0.094)$ & $-0.063(0.094)$ \\
\hline Difficulty paying bills (Most of the tin & & & \\
\hline
\end{tabular}


(Table 凹) contd....

\begin{tabular}{|c|c|c|c|}
\hline & Model 1 & Model 2 & Model 3 \\
\hline From time to time & & $-0.606 * * *(0.112)$ & $-0.622 * * *(0.112)$ \\
\hline Almost never/never & & $-1.019 * * *(0.115)$ & $-1.049 * * *(0.115)$ \\
\hline \multicolumn{4}{|c|}{ Urban area (Small/ middle sized town) } \\
\hline Large town & & & $-0.062(0.083)$ \\
\hline \multicolumn{4}{|c|}{ Region (Western Europe) } \\
\hline Southern Europe & & & $-0.682 * *(0.316)$ \\
\hline East-Central Europe & & & $0.118(0.254)$ \\
\hline Nordic Nations & & & $0.803 * *(0.368)$ \\
\hline Constant & $-3.687 * * *(0.241)$ & $-2.942 * * *(0.263)$ & $-2.887 * * *(0.302)$ \\
\hline Observations & 16,226 & 16,226 & 16,226 \\
\hline Number of groups & 28 & 28 & 28 \\
\hline \multicolumn{4}{|c|}{ Random-effects Parameters } \\
\hline \multicolumn{4}{|l|}{ Identity: Country } \\
\hline Variance (constant) & $0.298 * * *$ & $0.410 * * *$ & $0.247 * * *$ \\
\hline
\end{tabular}

Notes: $* * * \mathrm{p}<0.01, * * \mathrm{p}<0.05, * \mathrm{p}<0.1$; Standard errors in parentheses. All coefficients are compared to the benchmark category, shown in brackets.

Model 1 in Table 2 shows that the marginality thesis is valid when analysing various socio-demographic disparities in participation rates in undeclared work among urban dwellers. Not only are younger urban dwellers significantly more likely to participate in undeclared work, doubtless due to their greater exclusion from the formal labour market [12], but so too are those urban inhabitants more tolerant of undeclared work and holding non-conformist attitudes towards tax compliance, providing some support for the institutional theory explanation discussed above. That is, those marginalised in urban areas in the sense that their norms, values and beliefs regarding undeclared work do not conform to those of the formal institutions are more likely to participate in such work [66, 67].

Contrary to the marginality thesis however, urban men are significantly more likely to participate in undeclared work than urban women and so too are those urban inhabitants living in a single person household compared with those living in larger urban households. No significant correlation with participation in undeclared work is found when analysing the presence of children in urban household and the marital status of urban dwellers. As such, when considering the socio-demographic variables, the finding is that a variegated understanding of the validity of the marginality thesis is required. The marginality thesis is valid in relation to some marginal groups (such as younger urban people and those with non-conformist attitudes), but not others (such as urban women and single person urban households). The results are in line with other previous studies [68 - 70].

When Model 2 adds the socio-economic factors of employment status and financial circumstances people face to the socio-demographic variables, there are no major changes to the association of the socio-demographic variables with participation in undeclared work. Those socio-demographic characteristics statistically significant in Model 1 remain the same. However, the additional finding is that those urban dwellers with financial difficulties are significantly more likely to participate in undeclared work than those with fewer financial difficulties, thus providing support for the marginality thesis. However, no significant association with participation in undeclared work is found when analysing the employment status of urban inhabitants.

When spatial factors are added in Model 3, the association of the socio-demographic and socio-economic characteristics remain as discussed above. However, although there is no evidence to support the marginality thesis when those living in small urban areas are compared with those living in larger urban areas, those urban inhabitants living in the more affluent EU region of the Nordic nations are more likely to participate in undeclared work than those urban dwellers living in Western Europe, and those urban inhabitants living in Southern Europe are less likely. As such, there is no support for the marginality thesis when considering the town size divide and European regional variations. At a European regional level therefore, there appears to be support for the view that undeclared work is not a substitute for the declared economy. Rather, undeclared work appears to be more prevalent in economies where the declared economy is stronger, not least because more money is in circulation that can be used to purchase goods and services from undeclared work.

\section{DISCUSSION AND CONCLUSION}

To evaluate the marginality thesis, the results of a 2013 survey of participation in undeclared work in urban areas in the 28 member states of the European Union. Using multilevel mixed-effects logistic regression analysis, this has 
revealed support for the marginality thesis in relation to some groups. Younger urban dwellers are significantly more likely to engage in undeclared work as are those who are more tolerant of undeclared work (who are marginalised in the sense that their values and attitudes do not conform to those of the codes, regulations and laws of the formal institutions) and those who have difficulties paying household bills. Contrary to the marginality thesis meanwhile, urban men are found to be significantly more likely to work undeclared than urban women, as are those living in urban areas in the more affluent EU region of the Nordic nations. No significant relationship exists however, so far as the marital status, the presence of children in the household or the town size is concerned.

Examining the theoretical implications of these findings, the outcome is that a variegated interpretation of the marginality thesis is required when analysing urban Europe. The marginality thesis applies when examining some socio-demographic and socio-economic characteristics such as their age, tax morality and household financial circumstances. However, when gender, household size and regional variations are analysed, the marginality thesis is negated, and indeed reinforces the gender and European regional disparities found in the declared economy. When other characteristics are analysed moreover, such as the town size, marital status and the presence of children, no significant relationship with undeclared work is found in urban Europe. What is now required is to evaluate whether the findings are similar when examining urban areas in other global regions, especially in developing countries, and urban areas in particular nations, as well as rural areas.

Turning to the policy implications, the first important consequence is that these results display the specific spaces and populations that need targeting when seeking to tackle undeclared work in urban Europe. In recent years for example, there has been an emphasis in the European Union on targeting poorer EU regions such as East-Central and Southern Europe when allocating resources through European structural funds to tackling undeclared work [12, 71]. However, this paper reveals that urban areas in these poorer EU regions are not disproportionately engaged in undeclared work. Indeed, urban areas in affluent European regions have significantly higher participation rates, suggesting the need for a rethinking of the spatial allocation of European funds for tackling the urban undeclared economy. Although this survey reveals that it is inappropriate to target some marginal populations when tackling undeclared work (such as urban women, people living in small sized towns, and urban inhabitants in less affluent EU regions), it displays that it may be worthwhile targeting other marginal population groups such as younger urban dwellers, single-person urban households and those with household financial difficulties. This analysis, in other words, provides a useful risk assessment of the different marginal urban populations to enable an evaluation of the validity of the currently targeted populations.

In sum, this paper has revealed for the first time the need for a more nuanced approach towards the marginality thesis in the urban areas of the European Union. If this paper thus stimulates the emergence of a more variegated understanding of the validity of the marginality thesis in relation to urban Europe, then it will have fulfilled its objective. If it also encourages a deeper investigation of the policy implications of this more nuanced understanding, not least in terms of the urban populations being targeted by the authorities when tackling the urban undeclared economy and how resources are allocated, then it will have fulfilled its wider intention.

\section{CONFLICT OF INTEREST}

The authors confirm that this article content has no conflict of interest.

\section{ACKNOWLEDGEMENTS}

Declared none.

\section{REFERENCES}

[1] Ahmad AN. Dead men working: time and space in London's ('illegal') migrant economy. Work Employ Soc 2008; 22(2): 301-18. [http://dx.doi.org/10.1177/0950017008089106]

[2] Castree N, Coe N, Ward K, Samers M. Spaces of Work: global capitalism and the geographies of labour. London: Sage 2004.

[3] Katungi D, Neale E, Barbour A. People in low-paid informal work. York: Joseph Rowntree Foundation 2006.

[4] Statistical Update on Employment in the Informal Economy. Geneva: International Labour Organisation 2012.

[5] ILO 2013 Women and Men in the Informal Economy: statistical picture [Retrieved June18, 2015] Available from: http://laborsta.ilo.org/informal_economy_E.html

[6] Brill L. Women's participation in the informal economy: what can we learn from Oxfam's work?. Manchester: Oxfam 2011. 
[7] Slavnic Z. Political economy of informalisation. Eur Soc 2010; 12(1): 3-23. [http://dx.doi.org/10.1080/14616690903042724]

[8] Taiwo O. Employment choice and mobility in multi-sector labour markets: theoretical model and evidence from Ghana. Int Labour Rev 2013; 152(3-4): 469-92. [http://dx.doi.org/10.1111/j.1564-913X.2013.00189.x]

[9] Kesteloot C, Meert H. Informal spaces: the geography of informal economic activities in Brussels. Int J Urban Reg Res 1999; $23(2): 232-51$. [http://dx.doi.org/10.1111/1468-2427.00193]

[10] Leonard M. Informal Economic Activity in Belfast. Aldershot: Avebury 1994.

[11] Stănculescu M. Working conditions in the informal sector. South East Europe Review for Labour and Social Affairs 2005; 10(3): 7993.

[12] Employment and Social Developments in Europe 2013. Brussels: European Commission 2014.

[13] Reducing opportunities for tax non-compliance in the underground economy. Paris: OECD 2012.

[14] Schneider F. Size and development of the shadow economy of 31 European and 5 other OECD countries from 2003 to 2013: a further decline [Retrieved June 6, 2015] 2013. Available from: http://www.econ.jku.at/members/Schneider/files/publications/2013/ShadEcEurope31_ Jan2013.pdf

[15] Williams CC, Windebank J. Informal Employment in the Advanced Economies: implications for work and welfare. London: Routledge 1998.

[16] Williams CC, Windebank J. Reconceptualising paid informal exchange: some lessons from English cities. Environ Plann A 2001; 33(1): $121-40$. [http://dx.doi.org/10.1068/a33155]

[17] Williams CC. Beyond the formal economy: evaluating the level of employment in informal sector enterprises in global perspective. J Dev Entrep 2013; 18(4): 1-18. [http://dx.doi.org/10.1142/S1084946713500271]

[18] Schneider F, Williams CC. The shadow economy. London: Institute of Economic Affairs 2013. [http://dx.doi.org/10.1017/CBO9781139542289]

[19] Button K. Regional variations in the irregular economy: a study of possible trends. Reg Stud 1984; 18(3): 385-92. [http://dx.doi.org/10.1080/09595238400185381]

[20] Williams CC. Re-theorizing the informal economy in western nations: some lessons from rural England. Open Area Studies J 2010; 3: 1-11. [http://dx.doi.org/10.2174/1874914301003010001]

[21] Castells M, Portes A. World underneath: the origins, dynamics and effects of the informal economy. In: Portes A, Castells M, Benton LA, Eds. The Informal Economy: studies in advanced and less developing countries. Baltimore: John Hopkins University Press 1989; pp. 19-41.

[22] Leonard M. Invisible Work, Invisible Workers: the informal economy in Europe and the US. London: Macmillan 1998. [http://dx.doi.org/10.1057/9780230371873]

[23] Barbour A, Llanes M. Supporting people to legitimise their informal businesses. York: Joseph Rowntree Foundation 2013.

[24] Williams CC. Cash-in-Hand Work: the underground sector and the hidden economy of favours. Basingstoke: Palgrave Macmillan 2004. [http://dx.doi.org/10.1057/9780230506190]

[25] La Porta R, Shleifer A. The unofficial economy and economic development. Brookings Pap Econ Act 2008; 47(1): 123-35.

[26] La Porta R, Shleifer A. Informality and development. J Econ Perspect 2014; 28(3): 109-26. [http://dx.doi.org/10.1257/jep.28.3.109]

[27] Davis M. Planet of Slums. London: Verso 2006

[28] Meagher K. Identity Economics: social networks and the informal economy in Nigeria. New York: James Currey 2010.

[29] Gallin D. Propositions on trade unions and informal employment in time of globalization. Antipode 2001; 19(4): 531-49. [http://dx.doi.org/10.1111/1467-8330.00197]

[30] Evans M, Syrett S, Williams CC. Informal economic activities and deprived neighbourhoods. London: Department of Communities and Local Government 2006.

[31] Van Geuns R, Mevissen J, Renooy P. The spatial and sectoral diversity of the informal economy. Tijdschr Econ Soc Geogr 1987; 78(5): $389-98$. [http://dx.doi.org/10.1111/j.1467-9663.1987.tb01859.x]

[32] MacDonald R. Fiddly jobs, undeclared working and the something for nothing society. Work Employ Soc 1994; 8(4): 507-30. [http://dx.doi.org/10.1177/095001709484002]

[33] Pahl RE. Divisions of Labour. Oxford: Blackwell 1984.

[34] Renooy P. The Informal Economy: meaning, measurement and social significance, Koninklijk Nederlands Aardrijkskundig Genootschap, 1990.

[35] Williams CC. Tackling the participation of the unemployed in paid informal work: a critical evaluation of the deterrence approach. Environ Plann C Gov Policy 2001; 19(5): 729-49. 
[http://dx.doi.org/10.1068/c14m]

[36] Komter A. Reciprocity as a principle of exclusion: gift giving in the Netherlands. Sociology 1996; 30(2): $299-316$. [http://dx.doi.org/10.1177/0038038596030002006]

[37] Morris L. Informal aspects of social divisions. Int J Urban Reg Res 1994; 18(1): 112-26. [http://dx.doi.org/10.1111/j.1468-2427.1994.tb00253.x]

[38] Williams CC. The Hidden Enterprise Culture: entrepreneurship in the underground economy. Cheltenham: Edward Elgar 2006. [http://dx.doi.org/10.4337/9781847201881]

[39] Fortin B, Garneau G, Lacroix G, Lemieux T, Montmarquette C. L'Economie Souterraine au Quebec: mythes et realites. Laval: Presses de l'Universite Laval 1996.

[40] Cook D. Poverty, Crime and Punishment. London: Child Poverty Action Group 1997.

[41] Williams CC. Confronting the Shadow Economy: evaluating tax compliance behaviour and policies. Cheltenham: Edward Elgar 2014. [http://dx.doi.org/10.4337/9781782546047]

[42] Lemieux T, Fortin B, Frechette P. The effect of taxes on labour supply in the underground economy. Am Econ Rev 1994; 84(1): 231-54.

[43] McInnis-Dittrich K. Women of the shadows: Appalachian women's participation in the informal economy. Affilia 1995; 10(4): 398-412. [http://dx.doi.org/10.1177/088610999501000404]

[44] Williams CC, Round J, Rodgers P. The role of informal economies in the post-soviet world: the end of transition?. London: Routledge 2013.

[45] De Soto H. The Other Path: the economic answer to terrorism. London: Harper and Row 1989.

[46] De Soto H. The Mystery of Capital: why capitalism triumphs in the West and fails everywhere else. London: Black Swan 2001.

[47] Nwabuzor A. Corruption and development: new initiatives in economic openness and strengthened rule of law. J Bus Ethics 2005; 59(1/2): 121-38. [http://dx.doi.org/10.1007/s10551-005-3402-3]

[48] North DC. Institutions, Institutional Change and Economic Performance. Cambridge: Cambridge University Press 1990. [http://dx.doi.org/10.1017/CBO9780511808678]

[49] De Castro JO, Khavul S, Bruton GD. Shades of grey: how do informal firms navigate between macro and meso institutional environments? Strategic Entrepreneurship Journal 2014; 8(1): 75-94. [http://dx.doi.org/10.1002/sej.1172]

[50] Kistruck GM, Webb JW, Sutter CJ, Bailey AV. The double-edged sword of legitimacy in base-of-the-pyramid markets. J Bus Venturing 2015; 30(3): 436-51. [http://dx.doi.org/10.1016/j.jbusvent.2014.06.004]

[51] Siqueira AC, Webb JW, Bruton GD. Informal Entrepreneurship and Industry Conditions. Entrep Theory Pract 2016; 40(1): 177-200. [http://dx.doi.org/10.1111/etap.12115]

[52] Thai MT, Turkina E. Macro-level determinants of formal entrepreneurship versus informal entrepreneurship. J Bus Venturing 2014; 29(4): 490-510.

[http://dx.doi.org/10.1016/j.jbusvent.2013.07.005]

[53] Webb JW, Tihanyi L, Ireland RD, Sirmon DG. You say illegal, I say legitimate: entrepreneurship in the informal economy. Acad Manage Rev 2009; 34(3): 492-510. [http://dx.doi.org/10.5465/AMR.2009.40632826]

[54] Webb JW, Bruton GD, Tihanyi L, Ireland RD. Research on entrepreneurship in the informal economy: framing a research agenda. J Bus Venturing 2013; 28: 598-614. [http://dx.doi.org/10.1016/j.jbusvent.2012.05.003]

[55] Webb JW, Ireland RD, Ketchen DJ. Towards a greater understanding of entrepreneurship and strategy in the informal economy. Strategic Entrepreneurship Journal 2014; 8(1): 1-15. [http://dx.doi.org/10.1002/sej.1176]

[56] Williams CC, Shahid M. Informal entrepreneurship and institutional theory: explaining the varying degrees of (in) formalisation of entrepreneurs in Pakistan. Entrepreneurship and Regional Development 2016; 28(1-2): 1-25. [http://dx.doi.org/10.1080/08985626.2014.963889]

[57] Williams CC, Horodnic IA. Evaluating the prevalence of the undeclared economy in Central and Eastern Europe: An institutional asymmetry perspective. Eur J Ind Relat 2015; 21(4): 389-406. [http://dx.doi.org/10.1177/0143831X14568835]

[58] Williams CC, Horodnic IA. Tackling the informal economy in South East Europe: an institutional approach. Journal of South East European and Black Sea Studies 2015; 15(4): 519-39. [http://dx.doi.org/10.1080/14683857.2015.1056980]

[59] Williams CC, Horodnic IA. Evaluating the illegal employer practice of under-reporting employees'salaries. Br J Ind Relat 2016. [http://dx.doi.org/10.1111/bjir.12179] 
[60] Williams CC, Horodnic IA. An institutional theory of the informal economy: some lessons from the United Kingdom. Int J Soc Econ 2016; 43(7): 722-38. [http://dx.doi.org/10.1108/IJSE-12-2014-0256]

[61] Solon G, Haider SJ, Wooldridge J. What are we weighting for? J Hum Resour 2015; 50(2): 301-16. [http://dx.doi.org/10.3386/w18859]

[62] Winship C, Radbill L. Sampling weights and regression analysis. Sociol Methods Res 1994; 23(2): 230-57. [http://dx.doi.org/10.1177/0049124194023002004]

[63] Sharon SL, Liu J. A comparison of weighted and unweighted analyses in the National Crime Victimization Survey. J Quant Criminol 1994; 10(4): 343-60. [http://dx.doi.org/10.1007/BF02221280]

[64] Pfeffermann D. The role of sampling weights when modelling survey data. Int Stat Rev 1993; 61(2): 317-37. [http://dx.doi.org/10.2307/1403631]

[65] Snijders TA, Bosker RJ. Multilevel Analysis: an introduction to basic and advanced multilevel modelling. London: Sage 2012.

[66] Williams CC, Martinez A. Explaining cross-national variations in tax morality in the European Union: an exploratory analysis. Stud Trans Stat Soci 2014; 6(1): 5-17.

[67] Williams CC, Martinez A. Is the informal economy an incubator for new enterprise creation? a gender perspective. Int J Entrepreneur Behav Res 2014; 20(1): 4-19. [http://dx.doi.org/10.1108/IJEBR-05-2013-0075]

[68] Williams CC, Horodnic IA. Rethinking the marginalisation thesis An evaluation of the socio-spatial variations in undeclared work in the European Union Employee Relations. Employee Relations 2015; 37(1): 48-65.

[69] Williams CC, Horodnic IA. Beyond the marginalization thesis evaluating the participation of the formally employed in the shadow economy in the European Union. J Econ Stud. 2016; 43(03): 400-17.

[70] Williams CC, Horodnic IA. Evaluating the participation of marginalized populations in undeclared work in the Baltic Sea countries. J Contemp Eur Stud 2016; 1-17. [http://dx.doi.org/10.1080/14782804.2016.1228524]

[71] Dekker H, Oranje E, Renooy P, Rosing F, Williams CC. Joining up the fight against undeclared work in the European Union. Brussels: DG Employment, Social Affairs and Equal Opportunities 2010.

(C) Williams and Horodnic; Licensee Bentham Open

This is an open access article licensed under the terms of the Creative Commons Attribution-Non-Commercial 4.0 International Public License (CC BY-NC 4.0) (https://creativecommons.org/licenses/by-nc/4.0/legalcode), which permits unrestricted, non-commercial use, distribution and reproduction in any medium, provided the work is properly cited. 